\title{
'THE COOLIES WILL ELBOW US OUT OF THE COUNTRY': AFRICAN REACTIONS TO INDIAN IMMIGRATION IN THE COLONY OF NATAL, SOUTH AFRICA ${ }^{1}$
}

\author{
HeAther Hughes \\ University of Lincoln
}

There is an extensive literature on the experiences of Indians and Africans in colonial Natal, but almost none of it focuses on the relationships between them. This article explores one element of this relationship, namely the ways in which Africans reacted to Indian indentured workers. It looks briefly at the conditions of indenture, and dwells at greater length on Indians' experiences as small agricultural producers after their contracts of indenture had ended. The attitudes of African traditionalists and the new middle class are examined. The article ends by examining the relationship between the leading political leaders of Indians and Africans in early twentieth-century Natal, $M$. K. Gandhi and John Dube. It suggests that while the settler state had an interest in driving a wedge between Africans and Indians, such sentiments for separation were felt from below as well.

\section{Introduction}

From i 860 to I9II, Indian workers entered the Colony of Natal in southeast Africa under a system of indenture, jointly organised by the British rulers of both India and Natal and white employers of labour in Natal. This article examines the reception of these Indian workers by the indigenous African majority of Natal, and some of the consequences for later political organisation among oppressed groups. The central argument offered is that racialised access to jobs and especially land resulted in a discourse that reduced highly complex social groups to two apparently homogenous (and frequently opposed) racial categories, 'Africans' and 'Indians'. Further, it is argued that the separation between them was not only the result of familiar 'divide and rule' tactics from above; those down below also had a hand in its creation. ${ }^{2}$

It must be noted that there already exists a substantial literature on Indian immigrants' experiences in South Africa. Important work has been conducted on virtually every aspect of indenture and after: analyses of passenger lists, labour conditions, the recreation

Address correspondence to Heather Hughes, Faculty of Business and Law, University of Lincoln, Brayford Pool, Lincoln LN6 7TS, e-mail hhughes@lincoln.ac.uk 
of family and social life, the growth of political and labour organisation, the role of wealthier 'passengers' who travelled voluntarily to South Africa (and a great deal of attention has been paid to the most famous of these by far, M. K. Gandhi, who lived in South Africa from I893 to I9I4) and the (re-) emergence of a sense of 'Indianness' in South Africa. ${ }^{3}$

However, gaps remain. For a long time, the political context weighed heavily on scholarship. For instance, E. S. Reddy pointed out that apartheid more or less precluded any research by scholars from mainland India, a matter that is now being redressed. ${ }^{4}$ Again, other writings on South African history, including revisionist ones, tended to partition their subject matter along racial lines. (Such a mosaic approach to the characterisation of ethnic difference would not surprise scholars of ethnicity in the USA, for example.) Thus, two major works were published on the social history of the popular classes in Durban in the mid-I99os: one was on Indians, one on Africans. ${ }^{5}$ In his study, Freund wrote that 'Indians, as I have come to realise, have a perspective on South African society that is different from that of either whites or Africans'. ${ }^{6}$ Yet such a perspective, it could be further argued, has been formed out of the multiple interactions between Africans and Indians, sometimes shaped by them, sometimes by the not-sohidden hand of white settler domination. That kind of racial separation has tended to militate against a full appreciation of the variety of connections between these two differentiated groups. The key point here is that apart from moments of extreme racial tension, such as erupted in 1949 and $1985^{7}$, there has been little published on everyday relations between Africans and Indians. Bhana and Vahed's recent study has begun to address this neglected area; indeed, their first chapter is pointedly entitled 'Gandhi, Africans and Indians in colonial Natal' ${ }^{8}$. This study follows their work as an attempt to shed light on the nature and results of interaction between Africans and Indians during that historical phase.

First, an outline of Indian immigration and conditions of indenture is presented. This is followed by an account of Indians' experiences as agricultural producers in Natal, since it was here that the main challenge to Africans' security was perceived to lie, rather than in the urban milieu, which remained very small for the colonial period. Finally, an analysis of the sources of anti-Indian thinking among Africans, and how this translated into organised political activity, is presented. Here, the key figure of John Dube, the Natalbased first president of the African National Congress (ANC), is used to exemplify the central themes.

\section{Indian indentured labour and the Natal sugar economy}

Ever since the I 840 os when Britain extended its control over Natal, white settlers - like white settlers everywhere - had been anxious to discover some crop that would make them and the colony rich. After several failed experiments, including arrowroot, tea, coffee, cotton and sesame seed, sugar seemed to hold the greatest prospect. Ideally suited to the subtropical coastal belt on the southeastern coast of Africa, this natural sweetener would become Natal's 'green gold'. The planters faced major difficulties in achieving their own take-off, however, of which the paucity of indigenous labour was the most pressing. The approximately 350000 Africans residing in the Colony in the mid- $19^{\text {th }}$ 
century still had enough access to land not to be tempted by the wages or type of work in sugar. Roughly half of them lived in the so-called locations, large tracts of generally poor quality land that had been set aside for exclusively African habitation in I847. Since these were never adequate for all Africans' needs, the rest lived on private farms that had been abandoned to speculators after the various collapsed schemes. ${ }^{9}$ Not all planters faced a labour drought, but those who did managed to persuade the colonial government to organise the importation of bonded labour from another British possession, India. The first Indian workers arrived in I860; by the time the scheme ended half a century later, some I 52000 would have disembarked in Natal. They were joined by so-called 'passenger' Indians, better-off traders and professionals mostly from present-day Gujarat and largely Muslim, who came to Natal on their own account to supply the needs of their labouring compatriots.

Indian workers were indentured for an initial period of five years. Indenture essentially meant that workers were contracted to a single employer, wages were fixed (usually ten shillings per month for men and five for women, with an increase of one shilling per year) and working and living conditions were entirely at the discretion of the employer. ${ }^{10}$ Over the period of the scheme, two-thirds of immigrants came from Tamil- and Telugu-speaking areas of southern India, with the remaining third from Hindi-speaking districts in the Ganges valley. Twelve per cent of the total numbers of immigrants were Muslim, two per cent were Christian and the remainder were Hindu. A wide variety of castes was represented in their number, but most workers were from lower castes associated with agricultural pursuits. Two-thirds of the migrants were male. Many were, as Swan put it, distressed, despairing, diseased and even disabled; even then, leaving India was often a last resort in the battle against harsh environmental conditions and demanding overlords. ${ }^{11}$ Initially, all workers were assigned to sugar production, and over the entire period, about sixty per cent were employed in this sector, with the remainder being allocated to municipal, railway, mining and commercial employers.

Despite the diversity in language, religion, experiences of migration and employment, all these workers of Indian origin came to be treated in Natal as a homogenous, subordinated category: 'coolies'. ${ }^{12}$ Indians' place, in both geographical and social senses, continued to be very closely tied to their original reason for arrival and was also confined by subsequent discriminatory legislation. As one writer put it, 'the concept of an "Indian" group is almost entirely the product of discriminatory treatment and legislation that lumps all descendants of immigrants from India into one "racial" category." 13 The colonial authorities and white settlers found this convenient to their interests, especially after the granting of Responsible Government in I 893 strengthened the hand of the local planter class. The designation implied both servility and isolation. But many African people too, found such a designation convenient, though for rather different reasons.

Living and working conditions for the majority of indentured workers were poor in the extreme. On the plantations, 'overwork, malnourishment and squalid living conditions formed the pattern of daily life' for most workers. Supervision of work regimes by overseers was harsh and workers' movement severely proscribed. Organised protest among them was impossible, so that resistance was largely expressed in forms that included 'malingering, absenteeism, petty larceny, destruction of employers' property and desertion'. ${ }^{14}$ In the early I 870 , the Indian government halted emigration because of the critical reports taken home by returning migrants, and only resumed the scheme after 
renewed assurances by the Natal government that workers' treatment would be improved. Despite the institution of a new administrative post of Protector of Indian Immigrants, there was little that the authorities could or would do to insist upon such improvements.

Both Africans and Indians were employed on some plantations. Bhana and Vahed note that there is still a lack of research on how they interacted, though they speculate that friction was more likely to characterise relations than co-operation. They found a few cases of Africans employed as sirdars (overseers) in control of Indian workers, and cite instances of African maltreatment of Indian workers, but it is impossible to know how representative, or otherwise, this picture was. ${ }^{15}$

Sugar production was confined to a relatively narrow coastal strip of Natal as well as to the extent of the railway line south and north of Durban (a matter of some thirty miles in each direction until the I880s). The Division of Inanda, to the north of Durban, was the centre of the sugar industry. The fastest rate of increase in production in the Division occurred between I864 and I874, as the number of acres under cultivation rose from nearly 5000 to over I2 ooo, prompting the local district surgeon, Josiah Matthews, to declare Inanda to be "[t]he most enterprising and rising portion of the whole colony'. ${ }^{16}$ Sugar was by no means immune from depression and internal crisis, though, and many smaller planters-cum-millers drifted away to Australia or the Kimberley diamond fields as the industrial processes of sugar production were centralised comparatively early. The two largest mills in the colony were also located in Inanda, the Natal Central Sugar Company at Mount Edgecombe, and Tongaat. ${ }^{17}$ Sugar production recovered and expanded in the I880s and the resulting large number of estates in Inanda meant that the Indian population was higher here than in other divisions: by the late I 880 os, there were an estimated I 4 ooo, of whom 6000 were under indenture and 8000 were 'free'. ${ }^{18}$

\section{Indians as market gardeners}

After five years of indenture, workers could opt to return to India (which about a quarter did), re-indenture, or find work on their own account. Most in this last category either sought employment in towns or took to small-scale commercial farming, better known locally as market gardening. Most stayed in Natal, some drifted to the goldfields, all were prohibited from entry into the Orange Free State. There were periods of deep economic depression when significant numbers, having been 'free' for some time, contracted themselves back into indenture as a relief from the onerous taxes that came to be imposed on Indians. ${ }^{19}$ The Natal government's initial promise that the cost of the return passage could be exchanged for a small plot of land was soon abandoned; only fifty out of over I 3000 applications were ever granted. From their earliest entry into non-indentured economic activity, therefore, Indian agriculturalists lacked a safety net such as a location; instead they had to compete on the open market for access to land. ${ }^{20}$

At first, Indians rented land as close as they could to the markets for their produce. Even in Inanda, there was a certain amount available for this purpose, especially to the interior in the so-called mist belt, close to the large African location of the same name. Conditions in the area were unsuitable for the cane varieties then available and were in 
any case poorly served by roads. All this marginal farmland was in the hands of white owners, corporate and individual, absentee and local. Numbers of African tenants, between 4000 and 5000 up until the I890s, were farming such land, largely according to traditionalist/communal practices. No sooner had the initial period of indenture come to an end than they began to face competition. As early as I866, large parts of some farms in Inanda, such as Riet Rivier and Groeneberg, were leased to small-scale Indian growers. ${ }^{21}$

They rapidly emerged as the most reliable food producers in many coastal divisions of Natal, particularly Inanda, where they 'were the main producers of all crops other than sugar. ${ }^{22}$ The magistrate reported in I 876 that Indians were "the real agriculturalists of this Division ... But for them, maize would be at famine price, and vegetables would be strangers to our table. ${ }^{, 23}$ It was not long before most white landowners considered Indian tenants more desirable than African ones. One Inanda-based landlord voiced what by the I 880 os had become a common refrain, 'I can get my rent from a Coolie, whereas I find great difficulty in getting it from a Native. ${ }^{24}$ By the I 890 , G. H. Hulett, a solicitor in Verulam, the administrative centre of the Inanda Division, estimated that a full ninety per cent of civil cases in the Inanda magistrate's court were actions for the recovery of rent arrears from African tenants, an indication of the extent to which they were losing the struggle to maintain their foothold on private land. ${ }^{25}$

Freund has argued that the vigour of Indian agriculturalists' enterprise was due to the efforts they made in the years immediately after indenture to recreate social, cultural and familial life of a particular 'creolised variety', suited to the intense self-exploitation to which extended families seemed prepared to submit themselves: there were even stories of them working their gardens by moonlight. ${ }^{26}$ Many engaged in related activities, such as hawking or trading, to the same end. The success of Indian small growers should not be overestimated - most 'remained extremely poor and found less and less opportunity to advance their fortunes'. ${ }^{27}$ Yet there are two other possible reasons for the achievements of Indian small-scale farmers. One of these Africans themselves well recognised: the 'strangers' from abroad possessed no cattle. More than any other, it was this single factor that marked Indians as impossible to assimilate, as far as Africans were concerned. 'Three Coolies could live in space that one Kafir would want. Natives like cattle; Coolies do not', observed Jacobus Matiwane of Verulam. This meant they could use virtually all the land they rented for cultivation. ${ }^{28}$ Indeed, some landowners complained that Indian land use was very harsh on the soil for this very reason. Some African chiefs believed that this was why Indians always had food, even in lean periods, and could 'plunder' Africans who had nowhere else to buy when food was scarce. ${ }^{29}$

The other factor giving Indian growers a possible advantage was the nature of rent charged. ${ }^{30}$ In Inanda, and probably elsewhere on the coast, Indians were charged per acre, whereas Africans were charged per hut. It was customary to charge Africans an annually increasing amount per hut; Indians on the other hand were charged fifteen shillings to $\mathcal{E}_{\mathrm{I}}$ per acre for a fixed number of years. ${ }^{31}$ The acre rent could well have been the more favourable arrangement, since it did not matter how many people assisted in production, whereas this factor materially affected the amount Africans had to pay to the landowner: the more hands on the land, the more huts were required for them. Moreover, on much speculatively held land, Indians, like white tenants, leased acreage 
for specified periods, whereas Africans 'continued to pay per hut without any security of tenure'. ${ }^{32}$

Some Indian growers were able to purchase small plots, thus giving them a security that their African counterparts lacked, although this frequently involved them in usurious borrowing relationships with urban-based 'passengers'. The few who emerged as largescale commercial farmers produced cash crops like sugar and tobacco and employed both African and Indian labour. ${ }^{33}$ From the late I890s, there were extensive purchases of land of a different sort — not by time-expired Indian workers, but by town-based 'passenger' merchants, who, suffering from restrictive legislation on land ownership in urban areas, began to turn to farmland for investment. While waiting for property values to rise, they did what speculators before them had done, dividing their holdings into small parcels for rental to petty producers. Indian purchases were significant enough by the turn of the century to have a marked effect on land prices: in the north of Inanda division, 'before Indians began to buy, land was as low as $f_{\mathrm{I}}$ to $30 \mathrm{O}$ an acre, and now the average price is from $\mathcal{E}_{4}$ to $\mathcal{E}_{5}$ an acre', according to G. H. Hulett. ${ }^{34}$

\section{African responses to Indian farmers}

By the later part of the century, Indian producers seemed well entrenched in small-scale agricultural production on their own account, supplying the colony's towns with fresh produce, while African land hunger seemed to be worsening. African cultivators widely perceived a direct connection between these two trends, especially in areas with high Indian populations like Inanda. Examples abound: a local homestead head, Matyonovana, applied to remove to Zululand on the grounds that 'this place is overrun by coolies'. ${ }^{35}$ One induna (chiefly functionary) said Africans were troubled by being 'always in a state of scarcity owing to the land having been taken up so much by Indians ... the better lands had been taken possession of by Indians, and Natives had been given the worst land in the district.' A headman asked, 'how was it that the Indians, who were comparatively new arrivals, had been well provided with land, and the natives, who were the aboriginals of the country, had been turned off?' Yet another complained that 'they felt it very much when told to quit and leave their fathers' bones to be ploughed up by an Indian'. ${ }^{36}$

To a degree, anti-Indian feelings among traditionalist Africans arose out of what may be called their different 'cultures of production'. However, this difference was compounded by discriminatory practices and attitudes on the part of white landowners and officials. The rental practices of landowners have already been described; Africans were also keenly aware of the different laws and taxes that applied to Indians and themselves. As one Mkontshwana put it, 'Europeans loathed the Natives, whereas Natives thought much of the Europeans, and yet the latter even went to the length of putting the Coolie above the Native. ${ }^{37}$

Also contributing in large measure was a predisposition on the part of many whites who worked closely with Africans to protect 'their' charges. On his patrols, the Inanda Location Supervisor, Thomas Fayle, frequently admonished Africans over their cropplanting methods, telling them that 'the Government did not see why they should be beaten by the Coolies'. He persuaded them to plant their own tobacco, 'and thereby save 
what they pay to Coolies'; he urged the women to earn more for their fowls by taking them to Durban themselves, rather than selling to Indians who came around. He encouraged all and sundry by telling them 'that good Natives were employed in preference to Coolies in many places'. ${ }^{38}$ These were common themes in his conversations with people as he passed from garden to garden. In addition, the original purpose for Indian workers' entry into Natal left its residue of prejudice: 'to Africans and whites alike, the term "labourer" became synonymous with "coolie", and stood for a condition to be avoided'. ${ }^{39}$

Africans and whites alike found it convenient to blame Indians for all manner of social ills. A common example was the problem of drunkenness among Africans, especially (again) in the sugar districts, since sugar by-products were used to make various intoxicating brews. Treacle was the basic ingredient of the potent isitshimiyana, for example. While whites and Indians had free access to such types of liquor, there was complete prohibition for Africans: some of the most carefully exact definitions of the term 'Native' are to be found in colonial liquor legislation. ${ }^{40}$ There was a thriving illicit trade with Africans in items such as treacle and rum through the 'canteens' (eating houses for Africans), run by both whites and Indians. Yet Africans thought Indians particularly culpable: 'The Coolies...have become the feet of the Natives in getting grog, and that is causing our nation to die. They are also great thieves. They did not introduce theft, but they have greatly increased it. ${ }^{41}$

Another group of Africans who felt threatened by what they perceived as Indian success in agriculture were landowners on the mission stations. ${ }^{42}$ They had agitated for years to be able to purchase lots on the mission reserves - those tracts of land attached to mission stations that were under jurisdiction of the mission society, but which tended already to have populations of traditionalists on them. There had been a few experiments of this kind, but most were on a very small scale. The most notable example of the establishment of an African freehold community was Edendale, near Pietermaritzburg, where Africans pooled their resources with a Wesleyan missionary to buy a farm, which was then subdivided into individual plots. Generally speaking, Africans wishing to purchase land had to do so in competition with everyone else; there was as yet no legislative bar on who could buy. By the late i870s, Africans owned some 83000 acres in the colony. ${ }^{43}$ Thereafter, it became increasingly difficult as land prices increased rapidly, due to the expansion of sugar and other settler crops and, as noted earlier, to purchases by 'passenger' Indians.

In order to understand the attitudes of converts, the mission societies themselves need to be investigated, since a strong strand of anti-Indian prejudice can be traced to them. The foremost mission society in Natal was the American Zulu Mission (AZM), the local 'branch' of the American Board of Commissioners for Foreign Missions, (ABCFM), with its headquarters in Boston. It had been active in the region since the I840s; the emergence of an educated African middle class was almost entirely due to its efforts. ${ }^{44}$ The two most successful stations of the AZM happened to be sited very close to areas of intense sugar production: Amanzimtoti on the south coast, and in Inanda, on the borders of the location. In both of these places, it is not hard to find examples of anti-Indian sentiment. Rev. Herbert Goodenough, the missionary in charge of Amanzimtoti from I 88I and who became chairman of all the ABCFM's operations in southern Africa in the early I900s, voiced strong objections to land alienation on mission holdings, for fear that 
Indians would end up sub-leasing plots from Africans who had been given titles: this had already occurred on one of the few stations where individual titles had been tried, Umvoti. ${ }^{45}$

Perhaps the strongest anti-Indianism of all, however, was to be found at the Inanda mission station. The missionary in charge there from the I 840 os to the I870s was Daniel Lindley, in many ways more liberal and tolerant than his missionary peers. A product of American Midwest religious revivalism, he was an anti-slavery republican, deeply committed to the upliftment of his African 'parishioners'. Yet on the issue of Indian immigration, he was less than liberal and tolerant: 'the great majority of these imported labourers will never return to their native land ... they are indescribably wicked, and seem to me hopelessly lost, now and forever ... I look upon these Indians as a growing cloud on our social horizon. ${ }^{46}$ Other Inanda missionaries felt similarly. Mary Edwards, the head of Inanda Seminary, the premier institution for the education of African girls from the late I860s, went to great lengths to buy a large piece of land adjoining the school with her own money, in order to forestall the construction of barracks for Indian workers anywhere in the vicinity. ${ }^{47}$

Since they imbibed much else of the missionaries' world view and embraced it as their own, it may be fair to assume that such prejudice was passed on to the early generations of African converts. It is an assumption that is almost impossible to prove, because these very early converts left no written clues. However, it is surely more than coincidence that two members of the founding church at Inanda, James Dube and Patayi Mhlongo, were the fathers of the two most prominent African leaders in Natal in the first decades of the twentieth century, John Dube and A. W. G. Champion; both sons held pronounced anti-Indian views. ${ }^{48}$ There were intense political differences between them. Dube was always deeply conscious of status, the need for elite leadership, and for campaign tactics that were explicitly constitutional. Champion, as Natal leader of the Industrial and Commercial Workers Union (ICU), was far more willing to take a radical populist approach in order to appeal to workers. ${ }^{49}$ Yet there were also notable similarities: both were prospective landowners, and their African constituencies likewise faced competition of various kinds from Indians, whether as small growers or as field or urban workers. Champion's vociferous anti-Indianism is well known; ${ }^{50}$ Dube's, on the other hand, while sometimes noted, has been passed over as of little significance.

\section{John Dube's attitude to Indians}

John Langalibalele Dube ${ }^{51}$ was born at Inanda mission station in I87I. He schooled both locally and at Amanzimtoti, where the boys' seminary was located. He was among the first Africans from Natal to attend college abroad, at Oberlin in Ohio from I887-I89I. His health failed, however, and he travelled home, where the AZM found him a preaching post. He soon returned to the United States and was ordained at Union Theological Seminary in I899. He became pastor of the Inanda church, as his father had been before him. With a generous donation of land from the local African chief, Mqhawe, to whom he was closely related, he was able to realise his dream of establishing Ohlange, an industrial school to teach self-sufficiency, at Inanda in I90I. In I903, he founded the newspaper Ilanga lase Natal, which became an important mouthpiece for the African middle class. 
Dube came to wider prominence at the time of the so-called Bambatha rebellion in I906 - an armed uprising by African peasants against a new tax being imposed by the colonial state. He criticised the way the authorities handled the crisis, and sympathised with the aspirations of the resisters, although he decried their tactics. ${ }^{52}$ Dube thereafter became the leading representative of African converts in Natal and was active in associations campaigning for greater rights for them. He rose to the height of his power in I9I 2 when he was chosen as the first president of the ANC. After he lost the position in I9I7 over accusations about his attitudes to segregation, he became increasingly involved in regional Natal politics, participating in the founding of the Zulu ethnic nationalist organisation, Inkatha. He authored what is considered the first 'modern' novel in Zulu, Insila kaShaka, and a biography of the Nazarite church leader, Isaiah Shembe. ${ }^{53} \mathrm{He}$ also wrote extensively on education and Christianity. He was the first African to be awarded an Honorary $\mathrm{PhD}$ by a South African university (by the University of South Africa in I936). He died in I946.

Almost from the first issue of Ilanga, Dube made regular pronouncements about Indians (and allowed others to do the same). An item headed 'The Indian invasion' noted that 'we know by sad experience how beneath our very eyes our children's bread is taken by these Asiatics: how whatever little earnings we derive from Europeans, go to swell the purses of these strangers, with whom we seem obliged to trade ... ${ }^{54}$ Resentment was never far beneath the surface: 'we had land, we mortgaged the same, and now what once was our heritage is enjoyed by Indians. ${ }^{55}$ Many educated Africans believed that Indians were more hard-working than Africans. It was Jacobus Matiwane who observed, 'As a people, the Natives are not industrious like the Coolies: as a people we are not fond of work.' That was why it seemed to him that 'the coolies will elbow us out of the country'. ${ }^{56}$ It was a sentiment expressed many times in Ilanga.

The threat of losing access to land was a theme that Dube often voiced in other forums, such as to Commissions and in public speeches. 'Natal, to-day, was full of Indians who had usurped the positions which ought to be filled by the natives ... if the policy of the Government was continued, by which they introduced Indians in large numbers year by year, it was evident the aboriginal natives of Natal would go to the wall', he told the $1906-7$ Commission. ${ }^{57}$ Later, in I9I2, when attempting to persuade a large gathering of chiefs in Zululand to support the ANC, he pointed out to them that 'people like coolies have come to our land and lorded it over us, as though we, who belong to the country, were mere nonentities' ${ }^{58}$ Dube was a powerful and effective orator who sometimes exaggerated for effect, but the underlying message was clear.

Many writers have been fascinated by the extraordinarily close parallels between Dube's Ohlange school complex and Gandhi's first ashram at Phoenix, barely a mile away. Both were established at the start of the twentieth century as places of moral enrichment, learning and upliftment; both leaders saw the importance of the press in disseminating their ideas (Gandhi founded his Indian Opinion in the same year as Ilanga, I903, and they shared a printing press until Dube could afford his own); both were involved in what were then elitist political organisations, the Natal Native Congress (NNC) and the Natal Indian Congress (NIC), founded to defend the achievements of their members. Both leaders also aspired to speak for a far broader constituency of ordinary people, though strictly defined in racial terms. ${ }^{59}$ 
Though each had his own separate sources of inspiration, they shared at least one: the pre-eminent black American leader of the time, Booker T. Washington. Dube (who himself came to be dubbed the 'Booker T. Washington of South Africa') had long been impressed by Washington's gradualist approach to blacks' acceptance into civil society in America, had visited Washington's school at Tuskegee, Alabama, and had sought his endorsement for Ohlange (this would later be forthcoming, in I9I I). According to E. S. Reddy, Gandhi too admired Washington. ${ }^{60}$ Interestingly, Washington had risen very rapidly to national and international attention just a few years earlier as a result of his so-called 'Atlanta Compromise' speech, which expressed support for segregation in the famous words, 'in all things that are purely social we can be as separate as the fingers, yet one as the hand in all things essential to mutual progress' ${ }^{61}$

There was another locally powerful individual that they both turned to for support and guidance, 'a good friend to the Indians and natives, who called him their father'. ${ }^{62} \mathrm{He}$ was Marshall Campbell, one of the wealthiest and most influential sugar barons, controlling the vast Natal Estates as well as successfully promoting Natal sugar interests through his political career as Member of Legislative Assembly in Natal from I893, and later as a Union Senator. Although Campbell believed they should never have been brought to Natal, he did employ Indians on his estates in Inanda when he entered the sugar business in the I870s. An advisor to both Dube and Gandhi on matters of political organisation and strategy, he encouraged gradual social change and favoured careful control from a leadership which would use its influence to maintain order. He was an enthusiastic supporter of Dube's efforts at Ohlange, and regularly visited the school and made cash donations. Through his offices, the Governor of Natal, Sir Matthew Nathan, visited the school to open a new building in I908. Dube assured Campbell on several occasions that he would steer clear of politics, but that was before I9I2, when he became first president of the African National Congress. Campbell did encourage communication - it was under his auspices that Gandhi and Dube are known to have met. Again, when the Indian leader Gopal Krishna Gokhale visited South Africa in I9I2, Gandhi acted as his secretary, and he arranged for Gokhale to address a mass rally on Campbell's estate and also to meet Dube at Ohlange. ${ }^{63}$ But Campbell also favoured separation of advancement on racial lines.

Both Gandhi and Dube were receptive to such thinking: though they clearly respected each other as leaders, they defined their politics in narrowly racial terms. Neither could see any purpose in joint action; in fact, both perceived deep dangers in such a course. Dube favoured racial separatism largely because he feared the threat that Indians posed to African land rights, and could therefore see no common cause. He developed a deep respect for the tactics of passive resistance that Gandhi and his followers deployed in their first campaign in 1906, and was moved by the bravery of the resisters in the face of police brutality, but nevertheless felt that such tactics would be disastrous among Africans (and in any case, such direct action was not ANC style at all). ${ }^{64}$ Gandhi rejected any alliance because, according to some, he saw common treatment with Africans as degrading, and according to others, he felt it would have damaged Africans' cause. ${ }^{65}$

It is somehow fitting that Campbell should be at the centre of an episode that reveals the levels of separation, competition (and on Dube's part, resentment) between African and Indian leaders. Meetings were organised in Durban in I9I6 to congratulate Campbell on the award of his knighthood. The Indians managed to be the first to organise their 
event, and had been able to secure the Town Hall for their lavish celebration. Dube's application for use of the same venue was rejected on the grounds that Africans were not clean enough. Therefore, the African gathering had to be held in the open near the racecourse. In his speech before Campbell's arrival, Dube told the audience, 'It is you people who helped to build the Town Hall, every bit of it. You carried the bricks and the stones, and mixed the cement. We are the people of the land, we were born here, and yet we have been refused, whereas the Indians were not'. ${ }^{66}$

\section{Conclusion}

The theme of African attitudes to Indian immigrants is perhaps more than a footnote in the story of international labour migration, because of the long-term social and political consequences that it would bring in its wake. It would be misleading to suggest that Africans, whether traditionalist or educated, laid all their grievances at the door of Indians; the record is also replete with criticisms of colonial officialdom and white settlers themselves. Yet it is also the case that the presence of Indians served to deflect much tension away from the colonial state: it was a classic case of people with equally little purchase on Natal's land and labour policies blaming each other. It would take decades before the separate and parallel political paths of their organisations came to be replaced with a commitment to solidarity in the achievement of a non-racial future on the part of leadership. Yet, in the layers of society below the leadership, tensions between the African majority and Indian minority would continue, however internally differentiated these two groups were.

\section{References}

${ }^{1}$ This article began life as a presentation to the African Studies Seminar at the University of Natal (as it was then called) in 2000. Many thanks go to the participants, as well as to the anonymous readers for this journal.

${ }^{2}$ In I9Io Natal, together with the Cape (a British possession since I8I5) and the former Afrikaner republics of the Orange Free State and the Transvaal (which had fallen to the British after the I 899-I902 South African war, fought over control of the goldfields), formed the Union of South Africa. 'South Africa' was often used as a geographic expression before I9Io, however, to denote all these regions under white control. While mining was central to South Africa's modern industrial development, it is no more than a backdrop to the story told here. For a good overview of the bigger picture, see W. Beinart, Twentieth-Century South Africa. (Oxford, I994).

${ }^{3}$ For general overviews of Indians in South Africa, see F. Ginwala, 'Class, consciousness and control: Indian South Africans I 860-I946’. Unpublished PhD thesis, University of Oxford, I974; B. Pachai, ed., South Africa's Indians: The Evolution of a Minority. (Washington, I979); S. Bhana and J. Brain, Setting Down Roots: Indian Migrants in South Africa 1860-1911, (Johannesburg, I990) and C. G. Henning, The Indentured Indian in Natal, 1860-1917. (New Delhi, I993). A useful compendium of primary documentation is Y. S. Meer et al., eds., Documents of Indentured Labour: Natal 1851-1917. (Durban, I980). On labour/economic issues, see B. Freund, Insiders and Outsiders. The Indian Working Class of Durban, 19101990. (Portsmouth and London, I995) and V. Padayachee and R. Morrell, 'Indian merchants and dukawallahs in the Natal economy, cr875-I9I4', Journal of Southern African Studies, vol. I7, no. I (I99I) pp. 7I-IO2. On political organisation, particularly important studies include M. Swan, Gandhi: the South African Experience. (Johannesburg, I985); S. Bhana, Gandhi's Legacy: the Natal Indian Congress 1984-1994. 
(Pietermaritzburg, I997); and S. Bhana and G. Vahed, The Making of a Political Reformer: Gandhi in South Africa, 1983-1914. (New Delhi, 2005). On identity formation, see G. Vahed, 'Constructions of community and identity among Indians in colonial Natal, i860-г9го: the role of the Muharram festival', Journal of African History, vol. 43 (2002) pp. 77-93 and R. Ebr.-Vally, 'Diversity in the imagined Umma: the example of Indian Muslims in South Africa' in A. Zegeye, ed., Social Identities in the New South Africa. (Cape Town and Maroelana, 200I) pp. 269-300. Although somewhat elderly now, two studies that were produced at the height of the revisionist 'wave' in southern African studies remain valuable overviews of more general land and labour issues in Natal: P. Richardson, 'The Natal sugar industry in the nineteenth century' in W. Beinart, P. Delius and S Trapido, eds., Putting a Plough to the Ground: Accumulation and Dispossession in Rural South Africa 1850-1930. (Johannesburg, I986) pp. I29-I75 and H. Slater, 'The changing pattern of economic relationships in rural Natal, I838-I9I4' in S. Marks and A. Atmore, eds., Economy and Society in Pre-Industrial South Africa. (London, I980) pp. I48-I70.

${ }^{4}$ E. S. Reddy, 'Indian research and publication on South Africa', ANC online archive at http:// www/anc/org/za/un/reddy/research/html [accessed I2 December 2006]. As an example of recent scholarship, see A. Nauriya, The African Element in Gandhi. (New Delhi, 2006).

5 The two studies are P. Maylam and I. Edwards, eds. The People's City. African Life in TwentiethCentury Durban. (Portsmouth and Pietermaritzburg, 1996) and Freund, Insiders and Outsiders.

${ }^{6}$ Freund, Insiders and Outsiders, p.xi.

${ }^{7}$ On the I949 African-Indian conflict, see E. Webster, 'The I949 Durban "riots": a study in race and class' in P. Bonner, ed., Working Papers in Southern African Studies Volume 1. (Johannesburg, I977). On the conflict in 1985, see H. Hughes, 'Violence in Inanda, August 1985', Journal of Southern African Studies vol. I3, no. 3 (I987) pp. 33 I-354.

${ }^{8}$ Bhana and Vahed, The Making of a Political Reformer, pp. 26-50. Bhana and Vahed survey an area that is not covered here, the anti-African attitudes which developed among Indian immigrants. It ought to be noted that insightful work has been undertaken in other fields, notably linguistics: see R. Mesthrie, Language in Indenture: a Socio-Linguistic History of Bhojpuri-Hindi in South Africa (Johannesburg, I99I). The emergence of such patois forms testifies to the levels of interaction between Africans and Indians on an everyday basis.

${ }^{9}$ For an analysis of early African attitudes to industrial time and discipline, see K. Atkins, The Moon is Dead! Give us our Money! The Cultural Origins of an African Work Ethic, Natal, South Africa 1843-1900. (London, I993).

${ }^{10}$ See P. van den Berghe, Caneville. (Middletown, I964) p. 2I, and S. Marie, Divide and Profit: Indian Workers in Natal. (Durban, I986) p. I6.

11 Swan, Gandhi: the South African Experience, p. 20. Information on the profile of workers is drawn from G. Vahed, 'Constructions of community', p. 78 and J. Brain, 'From co-operation, through competition, to conflict' in A. Duminy and B. Guest, eds., Natal and Zululand from Earliest Times to 1910: a New History. (Pietermaritzburg, I989) p. 25I.

12 See Vahed, 'Constructions of community', p. 79. See also the study by E. V. Daniel, 'The making of a coolie' in H. Bernstein, E.V. Daniel and T. Brass, eds., Plantations, Proletarians and Peasants in Asia. (London, I992) which shows how this term came to be used in a dehumanising way in many colonial situations where indentured Indian workers had been introduced.

${ }^{13}$ van den Berghe, Caneville, p. 35. See also the useful discussion on identity formation in R. Morrell, J. Wright and S. Meintjes, 'Colonialism and the establishment of white domination, I840-I890' in R. Morrell, ed., Political Economy and Identities in KwaZulu-Natal: Historical and Social Perspectives. (Durban, I996) pp. 52-55.

${ }^{14}$ Both quotes in this paragraph are from Swan, Gandhi: the South African Experience, pp. $26-7$.

15 Bhana and Vahed, The Making of a Political Reformer, pp. 28-9.

16 Figures are derived from the annual Blue books, I864-I874 and P. Richardson, 'The Natal sugar industry, I849-1905: an interpretive essay' in B. Guest and P. Sellers, eds., Enterprise and Exploitation in a Victorian Colony, (Pietermaritzburg, I985) p. I86. Matthews's description is in his Incwadi Yami, or Twenty Years' Personal Experience in South Africa. (Johannesburg, I976) [originally published I887] p.I2.

${ }^{17}$ R. Osborn, Valiant Harvest: the Founding of the South African Sugar Industry, 1848-1926. (Durban, I964) pp. $203-5$ and $249-55$.

${ }_{18}$ Inanda magistrate's report, 4 April i 888, Secretary of Native Affairs Papers, KwaZulu-Natal Archives Pietermaritzburg Repository, SNA I/I/IOS (I 88/I 888). 
${ }^{19}$ Swan, Gandhi: the South African Experience, pp. 24-5.

${ }^{20}$ Ginwala, 'Class, consciousness and control', p. 426 and Bhana and Brain, Setting Down Roots, p. 44.

21 Bhana and Brain, Setting Down Roots, p. 45.

${ }^{22}$ Freund, Insiders and Outsiders, p. I6.

${ }^{23}$ Report of Inanda magistrate, Blue book, I 876.

${ }^{24}$ Evidence of T. Rathbone, Minutes of Evidence to the South African Native Affairs Commission Volume 3, p. 905 .

${ }^{25}$ G. H. Hulett, Evidence Taken before the Natal Native Affairs Commission 1906-1907, p.942.

${ }^{26}$ Freund, Insiders and Outsiders, p. I6.

${ }^{27}$ Freund, Insiders and Outsiders, p. I 8.

${ }^{28}$ J. Matiwane, Evidence Taken before the Natal Native Commission, 1881, p. I46. The social and economic importance of cattle to African people could also explain why there was virtually no intermarriage between Indians and Africans in this period. Later there was a very small amount in the towns, but always on the margins of both social groups.

${ }^{29}$ For example, see letter from Chief Mqhawe of the Qadi to Secretary for Native Affairs, 3 March I 890 , SNA I/I/I23 (322/I890).

30 This argument was first advanced by H. Hughes, 'Violence in Inanda', p. 337.

31 Inanda magistrate to Secretary of Native Affairs, 24 February I886, SNA I/I/87 (7II/I886), and evidence of T. Rathbone, Minutes of Evidence to the South African Native Affairs Commission Volume 3 , p. 906.

32 J. Edley, 'The Natal Land and Colonisation Company in colonial Natal, I860-I890'. PhD, University of Natal, I99I, p. I I.

${ }^{33}$ Swan cites some instances of 'success stories': see Gandhi: the South African Experience, p. 22.

${ }^{34}$ G. H. Hulett, Evidence Taken before the Lands Commission, 1900-1902, p. 226.

35 Case of Matyonovana, August I889, in 'Applications from Natives for permission of Supreme Chief to remove from Division of Inanda', Verulam Magistrate's Papers, KwaZulu-Natal Archives Pietermaritzburg Repository, I/VLM 8/2.

${ }^{36}$ Statements by induna and others, Evidence Taken before the Natal Native Affairs Commission 1906-1907, pp.835, 840-I.

37 Statement of Mkontshwana, Evidence Taken before the Natal Native Affairs Commission 1906-1907, p. 842 .

${ }^{38}$ Extracts from Fayle's diary for I I January I890, SNA I/I/I22 (45/I890); Io August I890, SNA I/ I/I30 (968/i 890); 26 September i89i, SNA i/i/I47 (II8/i89i); and 26 September i892, SNA i/I/ I63 (I $304 /$ I 892 ).

39 Ginwala, 'Class, consciousness and control', p. 76.

40 See for example 'Comparative digest of laws affecting Natives', SNA I/I/3 I8 (645/ I 889).

${ }^{41}$ J. Matiwane, Evidence taken Before the Natal Native Commission, 1881, p. I47.

42 It should be noted that some chiefdoms were engaged in buying farmland (raising the deposits by levies on all homesteads) for those who could no longer be accommodated in locations. This was with the express purpose of ensuring a base for communal homestead production and in this sense ought to be distinguished from individual purchases by educated converts intent on commercial production. See J. Lambert, 'African reasons for purchasing land in Natal in the late $19^{\text {th }}$ and early $20^{\text {th }}$ centuries', UNISA online at http://www.unisa.ac.za/default.asp?Cmd=ViewContent\&ContentID= I I 72 [accessed 2 April 2007]

${ }^{43}$ Lambert, 'African reasons'.

44 The best general analysis of the AZM and the other mission bodies active in Natal (including the independent and politically important settlement at Edendale) remains N. Etherington,

Preachers, Peasants and Politics in South-East Africa, 1835-1880. African Christian Communities in Natal, Pondoland and Zululand. (London, I978).

${ }^{45}$ G. H. Hulett, Evidence Taken before the Lands Commission, 1900-1902, p. 226.

${ }^{46}$ Lindley, quoted in E. Smith, The Life and Times of Daniel Lindley (1801-1880): Missionary to the Zulus, Pastor to the Voortrekkers, Ubebe Omhlophe. (London, I949) p. 378.

47 A. Wood, Shine Where You Are. A History of Inanda Seminary, 1869-1969. (Alice, I970) p. 56.

${ }^{48}$ For brief notes on these two men, see Smith, The Life and Times of Daniel Lindley, pp. 283 and 4OI-3. 
49 Bradford notes the deep division that characterised worker as well as political organisation: see H. Bradford, A taste of freedom: the ICU in rural South Africa, 1924-1930. (Johannesburg, I987) especially pp. 260-I.

50 On Champion's attitudes towards Indians, see S. Marks, The Ambiguities of Dependence in South Africa. (Johannesburg, I986) chapter 3, and M. Swanson, ed., The Views of Mahlathi [Champion]. (Pietermaritzburg and Durban, I982).

${ }^{51}$ Because of Dube's prominence in early national politics as well as because of his considerable other achievements, he has been the subject of many studies. See for example S. Marks, The Ambiguities of Dependence, chapter 2; R. Hunt Davis, 'John L. Dube, a South African exponent of Booker T. Washington', Journal of African Studies vol. 2, no. 4 (I976) pp. 497-528; H. Hughes, 'Doubly elite: exploring the life of John Langalibalele Dube', Journal of Southern African Studies vol. 27, no.3 (200I) pp. 445-458. None has dwelt greatly on this aspect of his thought, however.

${ }^{52}$ For an analysis of Dube's position at this time, see S. Marks, Reluctant Rebellion: the 1906-1908 Disturbances in Natal. (Oxford I974) pp. 332-5, and M. Hadebe, 'A contextualisation and examination of the impi yamakhanda (I906 uprising) as reported by J. L. Dube in Ilanga lase Natal, with special focus on Dube's attitude to Dinuzulu as indicated in his reportage on the treason trial of Dinuzulu'. Unpublished MA dissertation, Historical Studies, University of Natal, 2003.

${ }^{53}$ Dube's anti-Indianism did not translate itself into support for segregation in the sense of legislative measures for the protection of African land. In fact he was deeply opposed to legislation such as the Land Act of I9I3, which enforced the possessory segregation of land along racial lines, although he came to support such measures in the I930s. See Marks, The Ambiguities of Dependence, chapter 2.

${ }^{54}$ Ilanga lase Natal, I I December I903.

55 Ilanga lase Natal, 20 November I903.

56 J. Matiwane, Evidence Taken before the Natal Native Commission, 1881, p. I45.

57 John Dube, Evidence Taken before the Natal Native Affairs Commission 1906-1907, pp. 960-I.

58 Speech in Eshowe, 30 November I9I2, Unclassified Dube papers, Killie Campbell Africana Library Durban, MS I093 document Ri56/I9I2/32.

59 They also shared a lifespan over virtually the same period: Dube I87I to I946, and Gandhi I869 to I 848 .

${ }^{60}$ E. S. Reddy, 'Mahatma Gandhi and John Dube' at the ANC archive online, http://www.anc.org.za/ ancdocs/history/people/gandhi/4.html [accessed I7 November 2006].

${ }^{61}$ B. T. Washington, Atlanta exposition speech, September I895, at the Library of Congress African Odyssey Project, http://www.loc.gov/ammem/aaohtml/exhibit/aopart6.html\#0605.

${ }^{62}$ Ellen Campbell, biographical sketch, in Marshall Campbell Papers, Killie Campbell Africana Library Durban, KCM32848. Many have pointed to the profound ambiguity of that term 'friend' in the context of settler societies: see for example S. Trapido, "The friends of the natives": merchants, peasants and the political and ideological structure of liberalism in the Cape, I854-I9I0' in S. Marks and A. Atmore, eds., Economy and Society in Pre-Industrial South Africa. (London, I980) pp. 247-74.

${ }^{63}$ Swan, Gandhi: the South African Experience, p. 235; U. Mesthrie-Dhupelia, Gandhi's Prisoner? The Life of Gandhi's Son Manilal. (Cape Town, 2004) p. I04.

${ }^{64}$ E. S. Reddy has reproduced this valuable account of Dube's attitude to passive resistance (based on the memories of a member of the Phoenix ashram, R. M. Patel) in his 'Mahatma Gandhi and John Dube'.

${ }^{65}$ J. H. Stone III, 'M. K. Gandhi: some experiments with truth', Journal of Southern African Studies vol. I6, no. 4 (I990) pp. 725-728, and Bhana and Vahed, The Making of a Political Reformer, pp. 40-I. ${ }^{66}$ Report on gathering, Is August I9I6, Chief Natives Commissioners' Papers, KwaZulu-Natal Archives Pietermaritzburg Repository, File 247, I I79/I6. 